\title{
Lip and Oral Cavity Cancer Pathologic Distant Metastasis TNM Finding v8
}

National Cancer Institute

\section{Source}

National Cancer Institute. Lip and Oral Cavity Cancer Pathologic Distant Metastasis TNM

Finding v8. NCI Thesaurus. Code C132720.

A pathologic finding about one or more characteristics of lip and oral cavity cancer, following the rules of the TNM AJCC V8 classification system as they pertain to distant metastases. There is no pathologic M0 for lip and oral cavity cancer. 